\title{
DISIPLIN KERJA DAN PRODUKTIVITAS KARYAWAN PT. SEGATAMA LESTARI DENGAN DIMEDIASI OLEH KEPUASAN KERJA
}

\author{
Muhammad Adi Dafit ${ }^{1}$, Djoko Soelistya ${ }^{2}$, Eva Desembrianita ${ }^{3}$ Heni Agustina ${ }^{4}$ \\ 1,2,3) Universitas Muhammadiyah Gresik \\ 4 Universitas Nahdlatul Ulama Surabaya
}

\begin{abstract}
This study discusses the relationship between discipline and employee productivity performance through job satisfaction in organizational performance. In organizational goals, employee productivity is needed so that the organization's business continuity can be sustainable, therefore the importance of an appreciation for employee work activities. Employees also feel satisfied with the results of their performance. This study aims to show the importance of employee productivity for the company by looking at and paying attention to discipline as part of a sense of responsibility in realizing what is expected by the company. The research method used is quantitative by using research samples consisting of 83 employees who work in companies that move in the industry that produces furniture collections. Research models are carried out and tested using an analysis program applying the Partial Least Square (PLS) approach. This study indicates that work discipline has a significant effect on employee productivity through job satisfaction. Job satisfaction has a significant impact on employee productivity, and the field is having a considerable impact on work productivity through job satisfaction.
\end{abstract}
Keywords
: Work Discipline; Productivity; Job Satisfaction
Correspondence to
:djoko_soelistya@umg.ac.id

\begin{abstract}
ABSTRAK
Studi ini membahas hubungan kedisiplinan terhadap kinerja produktivitas karyawan melalui kepuasan kerja dalam sudut pandang kinerja di organisasi. Dalam tujuan organisasi produktivitas karyawan sangat diperlukan sehingga kelangsungan bisnis organisasi bisa berkelanjutan, oleh karena itu pentingnya suatu penghargaan terhadap aktivitas kerja karyawan supaya karyawan juga merasa kepuasan atas hasil dari kinerjanya. Penelitian ini bertujuan untuk menunjukan pentingnya produktivitas kerja karyawan bagi perusahaan, dengan melihat dan memperhatikan kedisiplinan sebagai bagian daria rasa tanggung jawab dalam mewujudkan apa yang diharapkan oleh perusahaan. Metode penelitian yang dipakai yakni kuantitatif melalui penggunaan sampel penelitian terdiri dari 83 karyawan yang bekerja pada perusahaan yang melakukan pergerakan pada industri yang memproduksi koleksi mebel dan model penelitian yang dilakukan serta pengujian menggunakan program analisis menerapkan pendekatan Partial Least Square (PLS). Hasil penelitian ini menunjukan bahwa disiplin kerja berpengaruh secara signifikan terhadap produktivitas karyawan melalui kepuasan kerja, kepuasan kerja berpengaruh signifikan terhadap produktivitas karyawan dan disiplin berpengaruh signifikan terhadap produktivitas kerja melalui kepuasan kerja.
\end{abstract}

\section{Kata Kunci \\ : Disiplin kerja, Produktivitas, Kepuasan Kerja}

Riwayat Artikel :

Received : 26 Juni 2021

Revised : 9 Juli 2021

Accepted : 17 Juli 2021 


\section{PENDAHULUAN}

Snell \& Bohlander (2012) menyatakan bahwa manajemen sumber daya manusia adalah tahapan untuk melakukan pengelolaan akan kemampuan seorang individu guna meraih tujuan dari organisasi ataupun perusahaan, itupun dikuatkan oleh pendapat Loshali dan Krishnan (2013) dalam Sunarsi (2019), organisasi yang melakukan penentuan akan signifikansi Sumber Daya Manusia serta pendekatan bisnis strategis mereka lebih menguntungkan dibandingkan dengan yang lain. Oleh sebab itu perusahaan perlu mempertimbangkan strategi dalam meningkatkan SDM mereka untuk memperoleh keuntungan yang maksimal dengan menjaga produktivitas sumber daya manusianya.

Produktivitas karyawan dapat diukur dari hasil pekerjaannya dan produktivitas yang bagus, mencerminkan berkualitasnya SDM pada suatu organisasi ataupun suatu perusahaan tersebut (Mathis \& Jackson, 2006)

Sedarmayanti (2012) mengatakan produktivitas kerja karyawan dapat dilihat perannya dalam menyelesaikan pekerjaan barang ataupun jasa yang sudah diselesaikannya dalam persatuan waktu. Dan Sutrisno dalam Alamet et al. (2020) bahwa disiplin kerja merupakan sebuah sikap hormat terhadap aturan perusahaan, yang mengakibatkan dirinya mampu melakukan penyesuaian menyelesaikan tugasnya tepat waktu.

Handoko (2016) mengemukakan job satisfaction atau kepuasan kerja yang diperoleh karyawan dalam kondisi emosional yang memberikan perasaan baik senang maupun tidak. Dan kepuasan dalam bekerja menggambarkan kepuasan pekerja ketika melakukan penyelesaian akan pekerjaannya dan hal tersebut memberikan nilai positif yang berdampak pada peningkatan produktivitas karyawan sehingga produktivitas perusahaan akan meningkat juga.

Hasibuan (2012) menyampaikan bahwa pekerja yang lebih menyukai dan menikmati kepuasan di luar pekerjaannya karena dapat merasakan kepuasan apabila hasil pekerjaannya dapat secara adil dihargai oleh perusahaan, maka daripada itu, pekerja secara sukarela akan mampu memprioritaskan tugasnya dengan baik.
Dengan penghargaan yang diperoleh dari perusahaan, pekerja akan berusaha semaksimal, sehingga pekerja dapat memenuhi akan kebutuhan sehari-hari. PT. Segatama Lestari satu di produksi mebel sejak tahun 1995 dan mempunyai tujuan memberikan hasil produk yang konsisten, memiliki kualitas yang tinggi dengan desain yang elegan, berkualitas yang berorientasi selain di dalam negeri juga maupun mancanegara, yang telah diperlihatkan dalam kegiatan export negara Asia, Eropa maupun Timur Tengah.

TABEL 1. Data Realisasi Hasil Pencapaian Hasil PT. Segatama Lestari

\begin{tabular}{ccccc}
\hline Tahun & $\begin{array}{c}\text { Kapasitas } \\
\text { SDM } \\
\text { Produksi } \\
\text { (ideal) } \\
\text { (M3) }\end{array}$ & $\begin{array}{c}\text { Tatget } \\
\text { Permintaan } \\
\text { Produk } \\
\text { (M3) }\end{array}$ & $\begin{array}{c}\text { Realisasi } \\
\text { (M3) }\end{array}$ & $\begin{array}{c}\text { Persentase } \\
(\%)\end{array}$ \\
\hline 2015 & 1400 & 1500 & 1418.12 & 94.54 \\
\hline 2016 & 1400 & 1600 & 1424.66 & 89.04 \\
\hline 2017 & 1500 & 1700 & 1468.02 & 86.35 \\
\hline 2018 & 1500 & 1800 & 1512.88 & 84.05 \\
\hline 2019 & 1500 & 2000 & 1626.88 & 81.34 \\
\hline \multicolumn{5}{c}{ RATA-RATA } \\
\hline
\end{tabular}

Sumber : Data Personalia, 2019

Dari tabel 1, terlihat bahwa pada lima tahun terakhir PT. Segatama Lestari, mengalami adanya adanya permasalahan didalam perusahaan, yang mana produktivitasnya mengalami penurunan, dalam asumsi awal penurunan tersebut diasumsikan adanya tingkat disiplin kerja, dan kepuasan kerja yang menurun, terlihat terlihat dari tingkat kehadiran karyawan dan pencapaian target hasil produksi yang di capai mengalami penurunan. Berikut adalah data ketidakhadiran karyawan PT. Segatama lestari yang tercatat lima tahun terakhir dari tahun 2015 hingga 2019.

TABEL 2. Data ketidakhadiran PT. Segatama Lestari

\begin{tabular}{ccccc}
\hline Tahun & $\begin{array}{c}\text { Jumlah } \\
\text { Kari } \\
\text { Kerja }\end{array}$ & $\begin{array}{c}\text { Jumlah } \\
\text { Pegawai }\end{array}$ & $\begin{array}{c}\text { Jumlah } \\
\text { Hari }\end{array}$ & $\begin{array}{c}\text { Persentase } \\
(\%)\end{array}$ \\
\hline 2015 & 294 & 502 & 98 & 33.33 \\
\hline 2016 & 299 & 502 & 144 & 48.16 \\
\hline 2017 & 291 & 502 & 174 & 59.79 \\
\hline 2018 & 291 & 502 & 169 & 58.08 \\
\hline 2019 & 294 & 502 & 185 & 62.93 \\
\hline RATA-RATA & & & 52.46 \\
\hline
\end{tabular}

Sumber : Data personalia, 2019 
Dari tabel 2, tingkat ketidakhadiran dalam dalm kurun lima tahun terakhir cukup tinggi walaupun terdapat penurunan di tahun 2018 tapi terjadi peningkatan kembali di tahun 2019 bila terus di biarkan hal ini tentu menjadi permasalahan yang serius bagi kedisiplinan kerja karyawan yang dapat mempengaruhi produktifitas.

\section{TINJAUAN PUSTAKA}

\section{Disiplin Kerja}

Disiplin kerja adala sebuah peralatan yang dipakai para manajer untuk melakukan komunikasi bersama karyawan supaya karyawan memiliki kesiapan dalam melakukan perubahan perilaku dan dapat memberikan peningkatan kerja yang baik atas dasar kesadaran seorang individu untuk melakukan pemenuhan seluruh aturan dari perusahaan (Rivai, 2009), dan disampaikan juga oleh Sutrisno (2017) bahwa disiplin kerja adalah suatu perilaku seorang individu yang disesuaikan bersama aturan, prosedur pekerjaan yang berlaku. Maka dari hal tersebut, disiplin kerja ialah suatu sikap ataupuntindakan serta perbuatan yang disesuaikan bersama aturan-aturan baik tertulis ataupun tak tertulis.

Pada dasarnya terdapat idnikatorindikator tingkatan disiplinpekerja di dalam sebuah perusahaan (Sutrisno, 2017), terdapat 3 indikator kedisiplinan kerja, yakni:

1. Memiliki ketaatan pada peraturan akan waktu.

Memberikan perhatian kepada jam masuk kerja, jam istirahat, jam pulang kerja yang tepat waktu sertadisesuaikan bersama peraturan yang berlangsung pada suatu organisasai ataupun perusahaan.

2. Memiliki ketaatan pada aturan organisasi ataupun perusahaan.

Aturan perusahaan tentang tatacara mengenakan pakaian dan juga tingkah laku ketika melakukan pekerjaannya.

3. Memiliki ketaatan pada aturan yang lainnya pada perusahaan.

Peraturan mengenai apa saja yang dibolehkan serta tak dibolehkan dilaksanakan untuk pekerja pada organisasi ataupun perusahaan

\section{Kepuasan Kerja}

Hartatik (2014) memberikan penjelasan yang lebih lanjut bahwasanya teori dari kepuasan kerja melakukan kegiatan guna melakukan pengungkapan apakah yang menjadikan sebagian individu merasa lebih puas pada pekerjaan mereka dibandingkan dengan individu-individu yang lain

Edduar Hendri (2016), Kepuasan kerja mencerminkan perasaan seseorang terhadap pekerjaannya. Ini nampak dari sikap karyawan terhadap pekerjaan dan segala sesuatu di lingkungan kerjanya. Kepuasan kerja menjadi menarik untuk diamati karena memberikan manfaat, baik dari segi individu maupun dari segi kepentingan industri.

Indy (2013) menyampaikan bahwa Kepuasan kerja berhubungan erat dengan sikap karyawan terhadap pekerjaannya sendiri, situasi kerja, kerjasama antarapimpinan dengan sesama karyawan dan epuasan kerja merupakan sikap umum yang merupakan hasil dari beberapa sikap khusus terhadap faktorfaktor pekerjaan, penyesuaian diri dan hubungan sosial individual di luar kerja. Kepuasan kerja sebaga hasil keseluruhan dari derajat rasa suka atau tidak sukanya tenaga kerja terhadap berbagai aspek dari pekerjaannya.

Vannecia et al., (2013) menjelaskan bermacam-macam indikator kepuasan kerja yang dipakai dalam pengungkapan akan karakter penting tentang pekerjaan yakni:

1. Pekerjaan itu sendiri (work it self).

Tiap pekerjaan membutuhkan sebuah ketrampilan khusus dibidangnya yang disesuaikan oleh setiap individu. Sulit ataupun mudahnya sebuah pekerjaan dan juga perasaan dari seorang individu, bahwasanya keahlian mereka diperlukan pada melaksanakan pekerjaan itu sendiri, dapat memberikan peningkatan ataupun memberikan pengurangan akan kepuasan kerja.

2. Atasan (Supervision)

Atasan yang baik memiliki makna sanggup memberikan respect pada pekerjaan bawahan mereka, sedangkan untuk bawahan, atasan dapat dirasa 
selaku figur ayah/ ibu/ teman serta sekaligus atasan.

3. Teman sekerja (Workers)

Faktor yang memiliki hubungan baik antara karyawan dengan atasan ataupun dengan karyawan yang lainnya, baik yang serupa ataupun yang memiliki perbedaan akan jenis ataupun tugas dari pekerjaan itu sendiri.

4. Promosi (Promotion)

Ialah faktor yang memiliki hubungan antara guna mendapatkan sebuah peningkatan akan jenjang karir selama bekerja.

5. Gaji/upah (Pay)

Ialah salah satu faktor untuk memenuhi kebutuhan hidup pekerja yang dirasa memiliki kelayakan ataupun tak layak.

\section{Produktivitas Kerja}

Sedarmayanti (2012) memberikan pengertian akan produktivitas kerja karyawan yakni sebuah hal untuk membandingkan antara hasil yang diraih pekerja dalam satuan waktu. Ataupun jumlah barang ataupun jasa yang bisa dibuat oleh seseorang/karyawan pada durasi waktu tertentu. Hal ini dapat disimpulkan bahwa perbandingan antara hasil yang diraih ataupun output bersama seluruh sumber daya yang dipakai (input) disebut produktivitas. dimensi yaitu:

Produktivitas dibagi dalam dua

1. Efektivitas berkaitan dengan hasil untuk pekerjaansecara maksimal, dalam arti pencapaian target yang memiliki keterkaitan bersama kualitas, kuantitas serta waktu.

2. Efisiensi yang memiliki keterkaitan pada upaya melakukan perbandingan dari masukan bersama realisasi dari pemakaiannya ataupun bagaimanakah pekerjaan itu sendiri dilakukan.

Sutrisno (2017) menyampaikan bahwa indikator-indikator produktivitas kerja antara lain:

1. Kemampuan

Memiliki kemampuan guna melakukan tugasnya. Kemampuan dan keterampilan yang dimiliki pekerja secara profesionalismenya ketika melakukan pekerjaannya. Hal tersebut memberi semangat untuk melakukan penyelesaian akan tugas yang dibebankan pada pekerja.

2. Memberikan peningkatan pada hasil yang diraih

Melakukan usaha guna memberikan peningkatan pada hasil yang ingin diraih. Hasil ialah satu diantara beberapa hal yang bisa dirasa oleh yang melakukan pekerjaan ataupun yang menikmati hasil dari pekerjaan itu sendiri, yang dapat meningkatkan produktivitas pekerjaan untuk tiap-tiap individu yang terikat pada sebuah pekerjaan.

3. Semangat kerja

Merupakan sebuah upaya guna apa yang dikerjakan telah dikerjakan dan dibandingkan lebih baik dari sebelumnya. Indikator tersebut bisa diamati berdasarkan etos kerja serta hasil yang diraih pada hari selanjutnya dilakukan perbandingan dengan hari kemarin.

4. Pengembangan diri

Selalu melakukan pengembangan pada diri guna memberikan peningkatan pada kemampuan bekerja. Mengembangkan diri bisa dilaksanakan melalui adanya tantangan dan harapan bersama yang akan dihadapi. Oleh karena itu diperlukan kuatnya tantangan, pengembangan diri secara mutlak. Hal tersebut sama dengan harapan untuk menjadi lebih baik dan memberikan dampak kepada kehendak pekerja guna memberikan peningkatan pada kemampuan karyawan.

5. Mutu

Kerap melakukan usaha guna memberikan peningkatanakanmutu lebih baik dari yang sudahberlalu. Mutu ialah sebuah hasil kerja yang bisa memperlihatkan kualitas kerja dari karyawan. Sehingga hal tersebut dapat memberikan peningkatan akan 
mutu yang memiliki tujuan guna memberi hasil yang paling baik yang dalam gilirannya dapat amat memberikan kegunaan untuk perusahaan serta dirisendiri.

6. Efisiensi

Kegiatan membandingkan antara hasil yang diraih bersama seluruh sumber daya yang dipakai, untuk itu m asukan serta keluaran ialah sebuah aspek produktivitas yang memberi dampak yang cukup signifikan pada sebagian pekerja.

\section{METODE PENELITIAN}

Penelitian mengenai“"pengaruh disiplin kerja, terhadap produktivitas dengan kepuasan kerja sebagai variabel intervening di PT. Segatama Lestarimemakai pendekatan kuantitatif. Sugiyono (2016), mendefinisikan metode kuantitatif adalah data penelitian berwujud angka-angka serta melakukan analisis data dengan memakai prosedur statistik. Adapun hipotesis yang dilakukan pengajuannya pada penelitian berikut yakni sebagai berikut:

H1: Terdapat pengaruh signifikan antara disiplin kerja terhadap produktivitas kerja.
$\mathrm{H} 2$ : Terdapat pengaruh signifikan antara disiplin kerja terhadap kepuasan kerja.

H3 : Terdapat pengaruh signifikan antara kepuasan kerja terhadap produktivitas kerja.

H4 :Terdapat pengaruh signifikan antara disiplin kerja terhadap produktivitas melaluikepuasan kerja.

Populasi pada penelitian berikut yakni semua Karyawan tetap PT. Segatama Lestari Gresik yang memiliki jumlah 502 orang, akan tetapi data yang dipakai di random melalui penggunaan rumus Slovin dengan batas toleransi kesalahan yang ditetapkan yakni $10 \%$, selaku uji instrumen, sebanyak 83 responden.

Teknik pengumpulan data yang dipakai pada penelitian berikut yakni metode kuesioner atau angket dimana teknik pengumpulan data yang dilaksanakan melalui metode memberikan serangkaian pertanyaan ataupun pertanyaan tertulis pada responden guna meminta jawaban dari responden.

\section{HASIL PENELITIAN}

Di dalam penelitian berikut, uji hipotesis memakai teknik analisis PLS dengan menggunakan smartPLS 3.0. Di bawah ini yakniskema model program PLS yang dilakukan pengujiannya, dapat dilihat pada gambar 1.

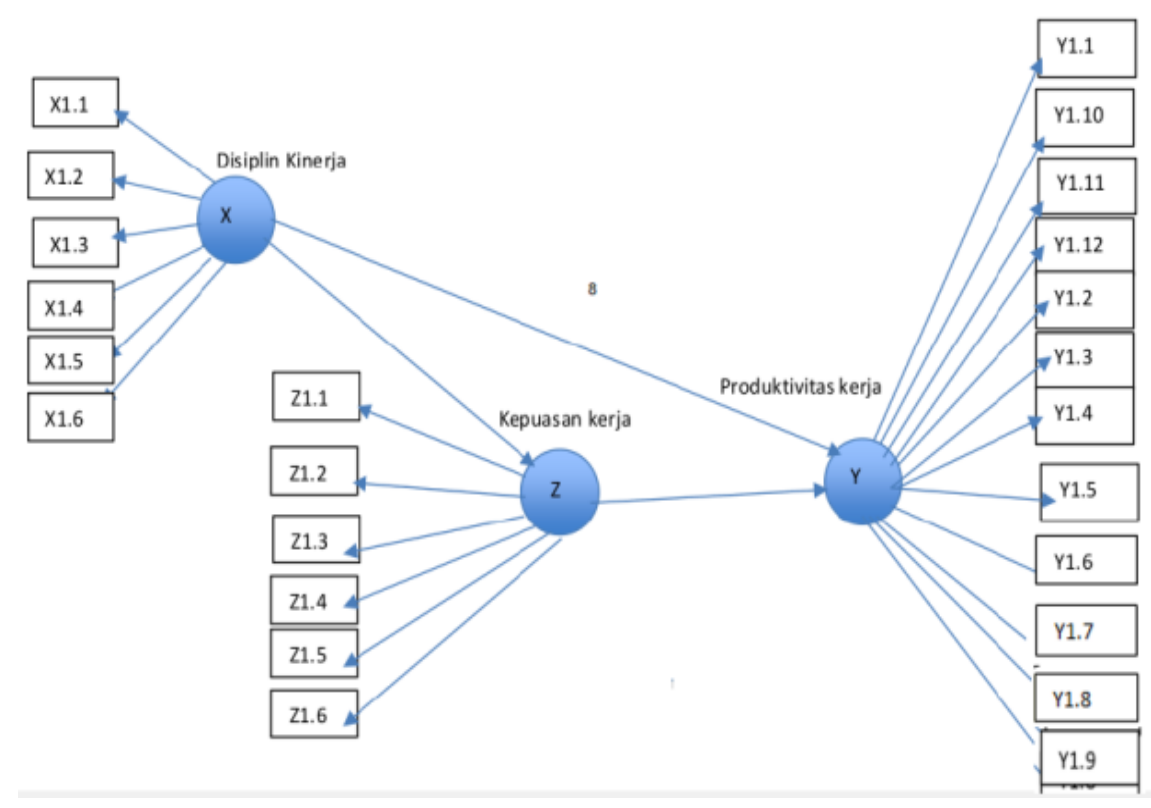

Sumber : Peneliti, 2020

Gambar 1. Skema Model Partial Least Square (PLS) 


\section{Evaluasi Measurement (Outer) Model}

Menurut hasil analisis PLS menggunakan PLS Algorithm bagi pengujian validitas juga reliabilitas, koefisien determinasi model serta koefisien jalur bagi model persamaan, berikut adalah gambar yang dihasilkan menurut hasil output PLS Algorithm SmartPLS, dapat dilihat di dalam gambar 2.

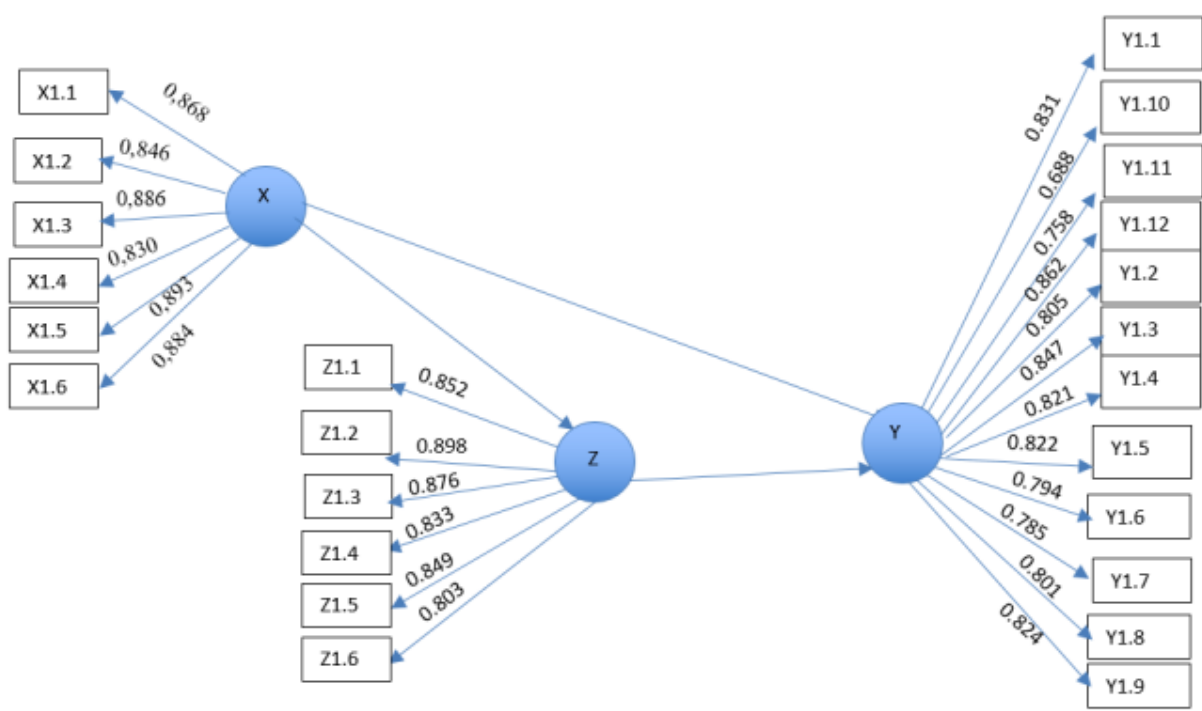

Sumber : Peneliti 2020

Gambar 2.

Evaluasi Measurement (Outer) Model

\section{Convergent Validity}

Ghozali dan Latan (2015) mengungkapkan Convergent validity dari model pengukuran menggunakan indikator refleksif bisa diamati berdasarkan korelasi antara item score ataupun indikator menggunakan score konstruknya. Ukuran reflektif individu dinyatakan tinggi apabila memiliki korelasi lebih dari 0,70 melalui konstruk yang hendak dilakukan pengukurannya. Akan tetapi melalui hal tersebut, di dalam riset tahap pengembangan skala, loading 0,50 hingga 0,60 masih bisa diterima. Di bahwa ini yakni nilai outer loading dari setiap indikator di dalam variabel penelitian:

TABEL 3. Outer Loading Convergent validity

\begin{tabular}{cccc}
\hline $\begin{array}{c}\text { Indika } \\
\text { tor }\end{array}$ & $\begin{array}{c}\text { Displin } \\
\text { Keja }\end{array}$ & $\begin{array}{c}\text { Kepuasan } \\
\text { Kerja }\end{array}$ & $\begin{array}{c}\text { Produktivita } \\
\text { s Kerja }\end{array}$ \\
\hline $\mathrm{X} 1.1$ & 0,868 & & \\
\hline $\mathrm{X} 1.2$ & 0,846 & & \\
\hline $\mathrm{X} 1.3$ & 0,886 & & \\
\hline $\mathrm{X} 1.4$ & 0,830 & & \\
\hline
\end{tabular}

\begin{tabular}{ccc}
\hline $\mathrm{X} 1.5$ & 0,893 & \\
\hline $\mathrm{X} 1.6$ & 0,884 & \\
\hline $\mathrm{Y} 1.1$ & & 0,831 \\
\hline $\mathrm{Y} 1.10$ & & 0,688 \\
\hline $\mathrm{Y} 1.11$ & 0,862 \\
\hline $\mathrm{Y} 1,12$ & 0,758 \\
\hline $\mathrm{Y} 1.2$ & 0,805 \\
\hline $\mathrm{Y} 1.3$ & 0,847 \\
\hline $\mathrm{Y} 1.4$ & 0,821 \\
\hline $\mathrm{Y} 1.5$ & 0,822 \\
\hline $\mathrm{Y} 1.6$ & 0,794 \\
\hline $\mathrm{Y} 1.7$ & 0,785 \\
\hline $\mathrm{Y} 1.8$ & 0,801 \\
\hline $\mathrm{Y} 1.9$ & 0,824 \\
\hline $\mathrm{Z} 1.1$ & \\
\hline $\mathrm{Z} 1.2$ & & \\
\hline $\mathrm{Z} 1.3$ & 0,852 & \\
\hline $\mathrm{Z} 1.4$ & 0,898 & \\
\hline $\mathrm{Z} 1.5$ & 0,876 & \\
\hline $\mathrm{Z} 1.6$ & 0,833 & \\
\hline
\end{tabular}

Sumber: Olahan Data Peneliti 2020

Berdasarkan tabel 1, bisa diamati bahwasanya setiap indikator variabel penelitian banyak yang mempunyai nilai outer loading $>$ 0,7. Akan tetapi, bisa diamati 
bahwasanya masih ada indikator-indikator yang mempunyai nilai outer loading $<0,7$.

Ghozali \& Latan, (2015), nilai outer load-nya antara $0,5-0,6$ telah dirasa mencukupi guna lolos akan persyaratan convergent validity. Data di atas memperlihatkan tak terdapat indikator variabel yang memiliki nilai outer loading di bawah 0,5 , yang menjadikan seluruh indikator dikatakan sebagai layak ataupun valid guna dipakai menjadi sebuah penelitian serta mampu dipakai guna menganalisa lebih lanjut.

\section{Discriminant Validity}

Discriminant validity indikator bisa diamati di dalam cross loading antara indikator melalui konstruk. Jika korelasi konstruk melalui indikatornya lebih tinggi apabila dilakukan perbandingannya dengan korelasi indikator melalui konstruksi yang lain, sehingga hal ini memperlihatkan bahwasanya konstruk laten memberikan prediksi indikator kepada bloknya lebih baik dengan melakukan perbandingan secara bersama dengan indikator pada blok yang lain. Di bawah ini yakni nilai cross loading setiap indikator:

TABEL 4. Cross Loading Discriminant Validity

\begin{tabular}{cccc}
\hline $\begin{array}{c}\text { Indikat } \\
\text { or }\end{array}$ & $\begin{array}{c}\text { Displin } \\
\text { Keja }\end{array}$ & $\begin{array}{c}\text { Kepuasan } \\
\text { Kerja }\end{array}$ & $\begin{array}{c}\text { Produktivitas } \\
\text { Kerja }\end{array}$ \\
\hline $\mathrm{X} 1.1$ & 0,868 & 0,280 & 0,288 \\
\hline $\mathrm{X} 1.2$ & 0,846 & 0,219 & 0,337 \\
\hline $\mathrm{X} 1.3$ & 0,886 & 0,268 & 0,283 \\
\hline $\mathrm{X} 1.4$ & 0,830 & 0,318 & 0,297 \\
\hline $\mathrm{X} 1.5$ & 0,893 & 0,245 & 0,248 \\
\hline $\mathrm{X} 1.6$ & 0,884 & 0,317 & 0,303 \\
\hline $\mathrm{Y} 1.1$ & 0,309 & 0,571 & 0,831 \\
\hline $\mathrm{Y} 1.10$ & 0,035 & 0,304 & 0,688 \\
\hline $\mathrm{Y} 1.11$ & 0,348 & 0,709 & 0,862 \\
\hline $\mathrm{Y} 1.12$ & 0,458 & 0,361 & 0,758 \\
\hline $\mathrm{Y} 1.2$ & 0,284 & 0,440 & 0,805 \\
\hline $\mathrm{Y} 1.3$ & 0,299 & 0,697 & 0,847 \\
\hline $\mathrm{Y} 1.4$ & 0,280 & 0,482 & 0,821 \\
\hline $\mathrm{Y} 1.5$ & 0,203 & 0,613 & 0,822 \\
\hline $\mathrm{Y} 1.6$ & 0,328 & 0,356 & 0,794 \\
\hline $\mathrm{Y} 1.7$ & 0,188 & 0,507 & 0,785 \\
\hline $\mathrm{Y} 1.8$ & 0,399 & 0,439 & 0,801 \\
\hline $\mathrm{Y} 1.9$ & 0,100 & 0,612 & 0,824 \\
\hline $\mathrm{Z} 1.1$ & 0,277 & 0,852 & 0,537 \\
\hline $\mathrm{Z} 1.2$ & 0,353 & 0,898 & 0,572 \\
\hline $\mathrm{Z} 1.3$ & 0,293 & 0,876 & 0,608 \\
\hline & & &
\end{tabular}

\begin{tabular}{llll}
\hline Z1.4 & 0,078 & 0,833 & 0,561 \\
\hline Z1.5 & 0,152 & 0,849 & 0,536 \\
\hline Z1.6 & 0,429 & 0,803 & 0,528 \\
\hline
\end{tabular}

Sumber: Olahan Data Peneliti 2020

Menurut tabel.2, dapat dilihat bahwasanya setiap indikator $d$ i dalam variabel penelitian mempunyai nilai cross loading paling besar di dalam variabel yang dibentuk apabila dilakukan perbandingan bersama nilai cross loading kepada variabel yang lain.

Menurut hasil yang didapatkan, bisa dikatakan bahwasanya seluruh indikator yang dipakai pada penelitian berikut sudah mempunyai discriminant validity yang baik ketika melakukan penyusunan pada setiap variabel. Serta disamping melakukan pengamatan dari nilai cross loading, discriminant validity bisa pula diketahui menggunakan metode yang lain yakni melalui nilai average variance extracted (AVE) (Fornell \& Larcker, 1981 dalam Ghozali, 2016).

Ghozali (2016) memberikan penjelasan bahwasanya pengujian yang ditujukan guna memberikan penilaian akan validitas dari konstruk melalui nilai AVE. Model dinyatakan baik jika AVE setiap konstruk nilainya $>0,50$.

TABEL 5. Average Variance Extracted (AVE)

\begin{tabular}{cc}
\hline Variabel & $\begin{array}{c}\text { Average Variance Extracted } \\
\text { (AVE) }\end{array}$ \\
\hline Produktivitas Kerja & 0.764 \\
\hline Kepuasan Kerja & 0.727 \\
\hline Disiplin Kerja & 0.681 \\
\hline
\end{tabular}

Sumber: Olahan Data Peneliti 2020

Menurut tabel 3, diketahui bahwamasingmasing variabel penelitian mempunyai nilai average varianceextracted (AVE) lebih besar dari 0,5, hal tersebut bisa dikatakan bahwa masing-masing variabel sudah mempunyai discriminant validity yang baik.

\section{Composite Reliability}

Composite Reliability ialah bagian yang dipakai guna melakukan pengujian akan nilai reliabilitas seluruh indikator di dalam sebuah variabel. Sebuah variabel bisa dikatakan 
memenuhi composite reliability jika mempunyai nilai composite reliability > 0,6. Di bawah berikut yakni nilai composite reliability dari setiap variabel yang dipakai pada penelitian berikut:

TABEL 6. Composite Reliability

\begin{tabular}{cc}
\hline Variabel & $\begin{array}{c}\text { Composite } \\
\text { Reliability }\end{array}$ \\
\hline Produktivitas Kerja & 0.948 \\
\hline Kepuasan Kerja & 0.941 \\
\hline Disiplin Kerja & 0.968 \\
\hline
\end{tabular}

Sumber: Olahan Data Peneliti 2020

Menurut tabel 4, bisa diamati bahwa nilai composite reliability seluruh variabel penelitian > 0,7. Konstruk dikatakan sebagai reliabel apabila nilai composite reliability ataupun cronbach alpha di atas 0,70 (Ghozali \& Latan, 2015). Hasil tersebut memperlihatkan bahwasanya setiap variabel sudah melakukan pemenuhan composite reliability maka bisa diberikan kesimpulan bahwa seluruh variabel mempunyai tingkatan reliabilitas yang tinggi.

\section{Cronbach Alpha}

Untuk menguji reliabilitas digunakan composite reliability di atas bisa diberikan penguatan melalui penggunaan nilai cronbach alpha. Sebuah variabel bisa dikatakan reliabel ataupun memberikan pemenuhan dari syarat cronbach alpha jika mempunyai nilai cronbach alpha> 0,7. Di bawah ini yakni nilai cronbach alpha yang diperoleh setiap variabel.

TABEL 7. Cronbach Alpha

\begin{tabular}{cc}
\hline Variabel & Cronbach's Alpha \\
\hline Produktivitas Kerja & 0.925 \\
\hline Kepuasan Kerja & 0.950 \\
\hline Disiplin Kerja & 0.964 \\
\hline
\end{tabular}

Sumber: Olahan Data Peneliti 2020

Berdasarkan tabel 5. bisa diamati bahwa nilai cronbach alpha oleh setiap variabel penelitian $>0,7$. Konstruk dikatakan reliabel apabila nilai composite reliability ataupun cronbach alpha di atas 0,70 (Ghozali dan Latan, 2015). Melalui hal tersebut hasil berikut bisa memperlihatkan bahwa setiap variabel penelitian sudah melakukan pemenuhan akan syarat nilai cronbach alpha, yang menjadikan bisa diberikan kesimpulan bahwa seluruh variabel mempunyai tingkat reliabilitas yang tinggi.

\section{Uji Model Struktural atau Inner Model}

Dalam penelitian berikut hendak diberikan penjelasan tentang hasil pengujian path coefficient, pengujian goodness of fit serta pengujian hipotesis

\section{Uji Path Coefficient}

Evaluasi path coefficient dipakai guna memperlihatkan seberapa kuat efek ataupun pengaruh variabel bebas pada variabel terikat. Sementara itu, coefficient determination (RSquare) dipakai guna melakukan pengukuran seberapa banyak variabel endogen diberikan pengaruhnya oleh variabel yang lain. Dan mendapat hasil R2 sejumlah lebih dari 0,83 guna variabel laten endogen pada model struktural memberikan indikasi akan pengaruh variabel eksogen (yang memberikan pengarah) terhadap variabel endogen (yang diberikan pengaruh) mencakup pada karakteristik baik. Dan apabila hasilnya sejumlah 0,33 - 0,67 sehingga mencakup pada kategori sedang, apabila hasil sejumlah $0,19-0,33$ maknanya mencakup pada kategori lemah.

Menurut skema inner model yang sudah disajikaN di gambar 4 sebelumnya bisa diberikan penjelasan bahwasanya nilai path coefficient paling besar diperlihatkan pengaruh Kepuasan kerja terhadap disiplin kerja yakni sejumlah 0,385 . Selanjutnya pengaruh paling besar nomor dua yakni pengaruh kepuasan kerja terhadap produktivitas kerja sebesar 0,540 , dari hasil penjabaran memperlihatkan bahwa seluruh variabel pada model tersebut mempunyai path coefficient yang memperoleh angka yang positif. Hal ini menunjukan bahwa apabila makin besar nilai path coefficient di dalam satu variabel bebas terhadap variabel terikat, sehingga makin kuat juga pengaruh antar variabel bebas terhadap variabel terikat.

\section{Uji Kebaikan Model (Goodness of Fit)}

Dari proses olah data yang sudah dilaksanakan diperoleh nilai R-Square yakni 
TABEL 8. Nilai R-Square

\begin{tabular}{cc}
\hline Variabel & R Square \\
\hline Kepuasan kerja & 0.171 \\
\hline Produktivitas kerja & 0.497 \\
\hline
\end{tabular}

Sumber: Data diolah 2020

Menurut tabel 6 bisa diamati bahwa nilai R-Square bagi variabel kepuasan kerja yakni 0,171. Perolehan nilai itu sendiri memberikan penjelasan bahwa persentase besarnya disiplin kerja bisa diberikan penjelasan oleh kepuasan kerja sejumlah $17,1 \%$.

Nilai R-Square yang didapatkan oleh variabel produktivitas kerja sebesar 0,497. Nilai tersebut memberikan penjelasan bahwa a disiplin kerja dan kepuasan kerja dapat sejumlah oleh produktivitas kerja sebesar $49.7 \%$

Penilaian goodness of fit bisa diamati berdasarkan nilai $Q$-Square. Nilai $Q$-Square mempunyai makna yang serupa dengan coefficient determination ( $R$-Square) di dalam analisis regresi, di mana makin tingginya $Q$ Square, sehingga model bisa dinyatakan makin baik ataupun makin fit menggunakan data. Adapun hasil perhitungan nilai $Q$ - Square yakni:

$$
\begin{aligned}
& \text { Q-Square }=1-[(1-\mathrm{R} 21) \times(1-\mathrm{R} 22)] \\
& =1-[(1-0,171) \times(1-0,497)] \\
& =1-(0,829 \times 0,503) \\
& =1-0,416 \\
& =0,584
\end{aligned}
$$

Menurut hasil perhitungan, didapatkan nilai Q-Square berjumlah 0,584. Perihal tersebut memperlihatkan besaran keragaman berdasarkan data penelitian yang bisa diberikan penjelasannya oleh model penelitian yakni sejumlah $58,4 \%$. Sementara itu sisanya sejumlah $41,6 \%$ diberikan penjelasannya oleh faktor lainnya yang terdapat di luar model penelitian berikut. Melalui hal tersebut, berdasarkan hasil itu sendiri sehingga model penelitian berikut bisa dikatakan sudah mempunyai goodness of fit yang baik serta positif.

\section{Uji Pengaruh Langsung}

Uji berikutnya yakni mengamati signifikansi pengaruh antar variabel melalui mengamati nilai koefisien parameter serta nilai signifikansi t-statistik yakni menggunakan metode bootstrapping (Ghozali \& Latan, 2015).

TABEL 9. $t$-Statistics dan $p$-Values

\begin{tabular}{ccccc}
\hline H & Variabel & $\begin{array}{c}\text { Original } \\
\text { Sample }\end{array}$ & $\begin{array}{c}\text { T Statistics } \\
(\mid \mathbf{O} / \text { STDEV|) }\end{array}$ & P Values \\
\hline $\begin{array}{l}\text { Disiplin kerja- } \\
\text { >Produktivitas } \\
\text { kerja }\end{array}$ & 0.225 & 2.289 & 0.023 \\
\hline 2 & $\begin{array}{l}\text { Disiplin kerja -> } \\
\text { Kepuasan kerja }\end{array}$ & 0,385 & 3.174 & 0.002 \\
\hline $\begin{array}{l}\text { Kepuasan kerja - } \\
\text { >Produktivitas } \\
\text { kerja }\end{array}$ & 0,540 & 5.137 & 0.000 \\
\hline \multicolumn{2}{l}{ Sumber: Olahan Data Peneliti 2020 } & &
\end{tabular}

Menurut tabel 7, diketahui bahwa dari empat hipotesis yang dilakukan pengajuannya pada penelitian berikut, seluruhnya bisa diterima sebab setiap pengaruh yang ditujukkan mempunyai nilaip-Values $<0,05$. Yang menyebabkan bisa dikatakan sebagai variabel bebas kepada terikatnya mempengaruhi secara signifikan.

\section{Uji Pengaruh Tidak Langsung}

Uji hipotesis pengaruh tak langsung dilaksanakan melalui metode teknik resampling bootstrapping. Pendekatan alternatif untuk menguji signifikansi mediasi (Bollen \& Stine, 1990, dalam Ghozali \& Latan, 2015).

TABEL 10. t-Statistics dan $p$-Values

\begin{tabular}{lcc}
\hline \multicolumn{1}{c}{ Variabel } & $\begin{array}{c}\text { T Statistics } \\
(\mid \mathbf{O} / \text { STDEV }])\end{array}$ & P Values \\
\hline $\begin{array}{l}\text { Disiplin kerja -> } \\
\text { Kepuasan kerja }\end{array}$ & 3.174 & 0.002 \\
\hline $\begin{array}{l}\text { Kepuasan kerja - } \\
>\text { Produktivitas kerja }\end{array}$ & 5.137 & 0.000 \\
\hline Sumber: Olahan Data Peneliti 2020 &
\end{tabular}

Menurut tabel 8, bisa diamati bahwa variabel independen mempengaruhi secara signifikan terhadap variabel terikat, variabel bebas mempengaruhi secara signifikan terhadap variabel mediator, variabel mediator mempengaruhi secara signifikan terhadap variabel terikat.

Maka menurut hasil di atas bisa dibuat sebuah kesimpulan bahwasanya variabel mediasi Kepuasan kerja merupakan variabel mediasi full (perfect mediation).

Mediasi penuh (full/perfect mediation) ada apabila pengaruh dari variabel bebas kepada variabel terikat dengan langsung yakni 
signifikan, namun pengaruhnya menjadi tak signifikan saat melibatkan variabel mediasi, dan dari hasil itu sendiri kemudian dilaksanakan uji hipotesis pengaruh tak langsung :

Tabel 11. $t$-Statistics dan $p$-Values

\begin{tabular}{lllll}
\hline H & Variabel & $\begin{array}{c}\text { Original } \\
\text { Sample }\end{array}$ & $\begin{array}{c}\text { T Statistics } \\
(\mid \mathbf{O} / \text { STDEV })\end{array}$ & P-Values \\
\hline 4 & Disiplin & 0.208 & 2.697 & 0.007 \\
& kerja -> & & & \\
& Kepuasan & & & \\
& kerja - & & \\
& $>$ Produktivi & & & \\
& tas kerja & & \\
\hline Sumber: Olahan Data Peneliti 2020
\end{tabular}

Sumber: Olahan Data Peneliti 2020

Menurut hasil perhitungan koefisien jalur, nampak bahwa total pengaruh disiplin kerja (X1) terhadap produktivitas kerja (Y) melalui kepuasan kerja diperoleh $t$-statistics sebesar 2.697 memperoleh $\rho$-value sejumlah 0,007 . Hal tersebut disebabkan oleh nilai $\rho$ value lebih kecil dibandingkan $\alpha(0,007<0,05)$ sehingga $\mathrm{H} 0$ ditolak melalui hal tersebut pengaruh signifikan disiplin kerja (X1) terhadap produktivitas kerja (Y) melalui kepuasan kerja (Z).

\section{PEMBAHASAN}

\section{Disiplin Kerja Berpengaruh Terhadap Produktivitas kerja}

Besarnya uji variabel disiplin kerja (X1) terhadap produktivitas kerja didapatkan nilai $t$-statistics sejumlah 2.289 memperoleh nilai $\rho$-value sejumlah 0,019 . Hal tersebut disebabkan nilai $\rho$-value kurang apabila dilakukan perbandingannya dengan $\alpha(0,019<$ $0,05)$ hal tersebut memiliki makna HO ditolak melalui hal tersebut terdapat kesimpulan terdapat pengaruh signifikan disiplin kerja (X1) terhadap produktivitas kerja (Y).

Keterkaitan disiplin kerja terhadap produktivitas kerja juga diperkuat dengan penelitian terdahulu oleh Winarsih et al. (2020), melakukan penelitian tentang disiplin kerja dan motivasi kerja terhadap produktivitas karyawan pada PT. Awfa Smart Media Palembang.

\section{Disiplin kerja Berpengaruh Terhadap Kepuasan kerja}

Hasil penelitian memperlihatkan uji variabel disiplin kerja (X1) terhadap kepuasan kerja didapatkan nilai $t$-statistics sejumlah 3.174 menggunakan $\rho$-value sejumlah 0.002 . Hal tersebut dikarenakan nilai $\rho$-value kurang dibandingkan dengan $\alpha(0.002<0,05)$ hal tersebut memiliki makna $\mathrm{H} 0$ ditolak melalui hal tersebut terdapat kesimpulan terdapat pengaruh signifikan disiplin kerja (X1) terhadap Kepuasan kerja (Z).

Hasil penelitian berikut selaras dengan hasil penelitian terdahulu oleh Alam et al. (2020), dalam penelitiannya tentang pengaruh disiplin kerja, komitmen organisasi dan lingkungan kerja terhadap kepuasan kerja karyawan pada CV. Pintu Mas Bogor.

\section{Kepuasan kerja Berpengaruh Terhadap Produktivitas kerja}

Uji variabel bisa diamati guna uji variabel kepuasan kerja (Z) terhadap produktivitas kerja (Y) didapatkan nilai $t$ statistics sejumlah 5.137 memperoleh nilai $\rho$ value sejumlah 0,000 . Hal tersebut disebabkan nilai $\rho$-value kurang dari apabila dilakukan perbandingan dengan $\alpha(0,000<0,05)$ hal tersebut memiliki makna $\mathrm{H} 0$ ditolak melalui hal tersebut terdapat kesimpulan terdapat pengaruh signifikan kepuasan kerja (Y) terhadap produktivitas kerja (Z).

Hasil penelitian berikut selaras dengan hasil penelitian Narpati et al. (2020). Melakukan penelitian dengan melakukan pengukuran akan implikasi turnover intention dan kepuasan kerja Sales Promotion Girl (SPG) terhadap produktivitas kerja di Matahari Department Store Metropolitan Mall Bekasi.

Penelitian ini memperlihatkan bahwasanya kepuasan kerja memiliki hubungan positif dengan produktivitas kerja. Kepuasan kerja mempunyai keterkaitan yang erat bersama produktivitas kerja.

\section{Disiplin kerja Berpengaruh Tidak Langsung Terhadap Produktivitas kerja Melalui Kepuasan kerja}

Berdasarkan hasil pengaruh disiplin kerja (X1) terhadap produktivitas kerja (Y) 
melalui kepuasan kerja diperoleh t-statistics sebesar 2.697dengan $\rho$-value sejumlah 0,007. Sebab nilai $\rho$-value kurang dari apabila dilakukan perbandingan dengan $\alpha(0,007<$ 0,05) hal tersebut memiliki makna H0 ditolak melalui hal tersebut terdapat kesimpulan terdapat pengaruh signifikan disiplin kerja (X1) terhadap produktivitas kerja (Y) melalui kepuasan kerja (Z).

Hasil penelitian sependapat dengan peneliti terdahulu Ariantiet al. (2019). Penelitian berikut mempunyai tujuan guna tahu akan pengaruh kompensasi, motivasi kerja dan disiplin kerja terhadap produktivitas kerja melalui kepuasan kerja.

\section{KESIMPULAN}

Dari hasil analisa data dan pembahasan dapat ditarik kesimpulan bahwa disiplin kerja mempengaruhi secara langsung terhadap produktivitas kerja, dapat diartikan jika disiplin kerja ditingkatkan maka produktivitas dapat mengalami peningkatan. Disiplin kerja mempengaruhi secara langsung terhadap kepuasan kerja, dapat diartikan jika disiplin kerja ditingkatkan sehingga kepuasan kerja dapat mengalami peningkatan. Kepuasan kerja mempengaruhi secara langsung terhadap produktivitas kerja, dapat diartikan jika kepuasan ditingkatkan sehingga produktivitas dapat mengalami peningkatan, begitupun kebalikannya jika kepuasan kerja tak ditingkatkan maknanya produktivitas kerja tidak meningkat. Disiplin kerja mempengaruhi secara tak langsung terhadap produktivitas kerja melalui kepuasan kerja, dapat diartikan bahwa disiplin kerja haruslah diperhatikan supaya kepuasan kerja tetap terjaga serta memberikan dampak terhadap produktivitas kerja, disiplin kerja ialah unsur utama guna mewujudkan kepuasan kerja.

Penerapan aturan dalam kedisiplinan sangat diperlukan supaya karyawan menjalankan pekerjaan sesuai policy perusahaan dengan begitu produktifitas perusahaan akan meningkat. Penghargaan terhadap hasil kinerja karyawan perlu dilakukan perusahaan, supaya karyawan merasakan kepuasannya bisa secara adil diperhatikan dan akan menambah semangat dalam bekerja untuk mendukung tujuan perusahaan.

\section{DAFTAR PUSTAKA}

Aamodt. (2011). Pengaruh Stres Kerja dan Lingkungan Kerja Terhadap Kinerja Karyawan. Skripsi. Bandung: Universitas Pasundan

Alam, I. K., \& Wanialisa, M. (2020). Pengaruh Disiplin Kerja, Komitmen Organisasi Dan Lingkungan Kerja Terhadap Kepuasan Kerja Karyawan Pada CV Pintu Mas Bogor. IKRA-ITH EKONOMIKA, 4(2), 172-180.

Arianti, S., Winatha, I. K., \& Rizal, Y. (2019). Pengaruh Kompensasi, Motivasi Kerja dan Disiplin Kerja terhadap Produktivitas Kerja Melalui Kepuasan Kerja Karyawan. JEE (Jurnal Edukasi Ekobis), 7(1).

Bhastary, M. D. (2020). Pengaruh Etika Kerja dan Stres Kerja Terhadap Kepuasan Kerja Karyawan. Maneggio: Jurnal Ilmiah Magister Manajemen, 3(2), 160-170.

Ghozali, I., \& Latan, H. (2015). Konsep, Teknik, Aplikasi Menggunakan Smart PLS 3.0 Untuk Penelitian Empiris. Semarang: BP Undip.

Ghozali, I. (2016). Aplikasi Analisis Multivariete Dengan Program IBM SPSS 23 (Edisi 8). Cetakan ke VIII. Semarang : Badan Penerbit Universitas Diponegoro.

Handoko, T. H. (2016). Manajemen (Edisi II.). Yogyakarta: BPFE.

Hartatik, I.P. (2014). Buku Praktis Mengembangkan SDM. Yokyakarta: Laksana

Hasibuan, M.S.P. (2014). Manajemen Sumber Daya Manusia. Jakarta: PT Bumi Aksara

Hasibuan, M.S.P. (2012). Manajemen Sumber Daya Manusia. Jakarta: PT. Bumi Aksara.

Hendra I.H. (2013). Hubungan Kepuasan Kerja Dengan Motivasi Kerja Pada Karyawan Bank BTPN Madiun. Jurnal Psikologi Industri dan Organisasi. Vol. 2 No. 2 
Hendri, E. (2016). Pengaruh Kepuasan Kerja Dan Semangat Kerja Terhadap Produktivitas Kerja Karyawan Pada PT. Selapan Jaya Ogan Komering Ilir. Jurnal Media Wahana Ekonomika, Vol 13, No.1, 1- 15

Mangkunegara, A.A.P. (2011). Manajemen Sumber Daya Manusia. Jakarta : Rineka Cipta.

Mathis, R. L., \& Jackson. J.H. (2015). Manajemen Sumber Daya Manusia. Buku II, Penerjemah: Jimmy Sadeli dan Bayu Prawira Hie. Jakarta: PT. Salemba Empat.

Misbahuddin \& Hasan, I. (2014). Analisis Data Penelitian dengan Statistik Edisi 2 Cetakan ke 2. Jakarta: Bumi Aksara.

Munandar, A. S. (2008). Psikologi Industri Dan Organisasi. Jakarta: UI Press

Narpati, B., Andrian, A., \& Nursal, M. F. (2020). Pengaruh Turnover Intention Dan Kepuasan Kerja Terhadap Produktivitas Kerja Sales Promotion Girl (SPG) Matahari Department Store-Bekasi. Business Management Analysis Journal 3(2), 174-188.

Noviani, R. D., Kurniawan, R., \& Kusasi, F. (2020). Pengalaman Kerja, Komitmen Organisasi Dan Stres Kerja Terhadap Produktivitas Kerja Pegawai Pada Dinas Kelautan Dan Perikanan Provinsi Kepulauan Riau. Student Online Journal (SOJ) UMRAHEkonomi, 1(1), 655-665.

Rivai, V., \& Sagala, E. (2009), Manajemen Sumber Daya Manusia Untuk Perusahaan. Jakarta: Raja Grafindo Persada.

Robbins, S. P., \& Judge, T. A. (2008). Perilaku Organisasi Edisi Ke-12. In Chemical And Petroleum Engineering.

Robins, S. P., \& Coulter, M. (2012). Management. In Angewandte Chemie International Edition. Https: //Doi.Org/ 10.1002/15213773 (20010316) 40:6 < 9823: Aid-Anie 9823 > 3.3.Co;2-C

Sedarmayanti. (2012). Good Governance: Kepemerintahan Yang Baik \& Good
Corporate Governance: Tata Kelola Perusahaan Yang Baik. Bagian Ketiga, Edisi Revisi. Bandung: Cv. Bandar Maju.

Snell, S, A. \& Bohlander, G, W. (2012). Managing Human Resources. SouthWestern: Cengage Learning.

Sugiyono, (2016). Metode Penelitian Kuantitatif, Kualitatif, Dan $R \& D$., Bandung: CV. Alfabeta

Sutrisno, E. (2017). Manajemen Sumber Daya Manusia, Jakarta: Prenada media Group.

Tan, Y. (2004). Metode Penelitian Untuk Akuntansi: Sebuah Pendekatan Praktis. Malang: Bayumedia Publishing

Vannecia \& Setiawan, R. (2013). Pengaruh kepuasan kerja dan loyalitas kerja terhadap organizational citizenship behavior pada karyawan PT. Surya Timur Sakti Jatim K. Agora, 1(1). 5566

Vannecia, et al. (2013). Pengaruh Kepuasan Kerja dan Loyalitas Kerja Terhadap Organizational Citizenship Behaviour Pada Karyawan PT. Surya Timur Jatim. Agora Vol.1, No.1

Winarsih, W., Veronica, A., N., \& Anggraini, A. (2020). Pengaruh Disiplin Kerja Dan Motivasi Kerja Terhadap Produktivitas Karyawan Pada PT. Awfa Smart Media Palembang. Jurnal Ilmiah Akuntansi Rahmaniyah, 3(2), 34-51.

Wirartha, I.M. (2015). Metode Penelitian Sosial Ekonomi. Yogyakarta: Andi Offset

Wisudawati, H. (2013). Pengaruh Stress Kerja Terhadap Produktivitas Kerja Melalui Kepuasan Kerja. Jurnal Ilmu Manajemen (JIM), 1(2). 